\title{
MEDIA PEMBELAJARAN IPA POKOK BAHASAN SISTEM PENCERNAAN MAKANAN SESUAI STANDAR KOMPETENSI
}

\author{
Achmad Ritfan Fathoni*,1, Edy Budiman², Rudiman ${ }^{3}$ \\ ${ }^{1,2,3}$ Program Studi Teknik Informatika, FKTI, Universitas Mulawarman \\ Jalan Barong Tongkok No. 6 Kampus Gunung Kelua Samarinda, Kalimantan Timur \\ Email : nokad.star@gmail.com ${ }^{1)}$, edy.budiman@gmail.com²), rudiman_38@gmail.com ${ }^{3)}$
}

\begin{abstract}
ABSTRAK
Pendidikan merupakan proses yang kompleks, sehingga pendidikan selalu mengikuti perkembangan manusia. Melalui pendidikan menengah berbagai aspek belajar mengajar dikembangkan, melalui proses belajar perlu diselaraskan dan distabilkan agar kondisi belajar tercipta sesuai dengan tujuan yang ingin dicapai serta dapat diperoleh hasil seoptimal mungkin. Untuk melengkapi komponen belajar dan pembelajaran sekolah, sudah seharusnya guru memanfaatkan media atau alat bantu yang mampu merangsang pembelajaran secara efektif dan efesien. Media pembelajaran merupakan salah satu unsur yang amat penting dalam proses belajar mengajar, di dalamnya terdapat pesan yang akan disampaikan kepada siswa berupa alat atau visualisasi berupa gambar serta video. Selain itu media pembelajaran ini bertujuan untuk peningkatan kualitas hasil belajar dan sarana berkomunikasi dengan siswa agar lebih efektif. Sistem dibangun dengan menggunakan metode sekuensial linier / waterfall. Pembuatan media pembelajaran ini berbentuk aplikasi portable yang bisa di jalankan di sistem operasi windows. Salah satu fungsi media pembelajaran ini di dalam proses belajar mengajar adalah sebagai alat bantu mengajar guru terhadap siswa. oleh karena itu penggunaan media pembelajaran saat proses belajar mengajar sangat diperlukan.
\end{abstract}

Kata kunci : Media Pembelajaran IPA, Sistem Pencernaan Makanan, Metode Sekuensial Linier / Waterfall

\section{PENDahuluan}

\subsection{Latar Belakang}

Pendidikan merupakan proses yang kompleks, sehingga pendidikan selalu mengikuti perkembangan manusia. Melalui pendidikan menengah berbagai aspek belajar mengajar dikembangkan, melalui proses belajar perlu diselaraskan dan distabilkan agar kondisi belajar tercipta sesuai dengan tujuan yang ingin dicapai serta dapat diperoleh hasil seoptimal mungkin. Untuk melengkapi komponen belajar dan pembelajaran sekolah, sudah seharusnya guru memanfaatkan media atau alat bantu yang mampu merangsang pembelajaran secara efektif dan efesien.

Manfaat aktivitas dalam pembelajaran disebabkan kemajuan ilmu dan teknologi adalah agar siswa dapat mencari sendiri dan lansung mengalami proses belajar. Belajar yang dimaksud berupa pembelajaran yang dilaksanakan secara realistik dan kongkrit, sehingga mengembangkan pemahaman dan berfikir kritis serta menghindari terjadinya verbalisme yang terus menerus. Penyampaian materi ajar yang tidak bervariasi dapat menjadi penyebab tidak tercapainya tujuan pembelajaran yang diinginkan. Dengan adanya variasi dalam pembelajaran diharapkan agar siswa dapat belajar sendiri yang pada akhirnya akan mengembangkan seluruh aspek pribadi siswa tersebut. Siswa dituntut untuk dapat menerapkan semua aspek yang didapat dari proses belajar, sehingga dapat menjadi individu-individu yang kreatif sebagaimana yang diungkapkan Conny R. Semiawan: strategi pembelajaran yang efektif dan

*Corresponding Authors efesien adalah pengembangan sikap belajar individu untuk mewujudkan pribadi yang tidak saja menguasai pengetahuan dan keterampilan dalam alih ilmu dan teknologi, tetapi juga dapat mengembangkan dirinya sesuai potensi, bakat dan minatnya menjadi pribadi yang kreatif dan berintegritas tinggi, (Ginanjar, 2010).

Penggunaan alat bantu atau media pembelajaran merupakan bagian yang tidak bisa dipisahkan dan sudah merupakan suatu integrasi terhadap metode belajar yang dipakai. Alat bantu belajar termasuk salah satu unsur dinamis dalam belajar. Kedudukan alat bantu memiliki peranan yang penting karena dapat membantu proses belajar siswa. Penggunaan alat bantu, bahan belajar yang abstrak bisa dikongkritkan dan membuat suasana belajar yang tidak menarik jadi lebih menarik. Banyak alat bantu atau media belajar diciptakan untuk belajar mandiri saat ini, namun untuk mencari suatu pilihan atau solusi alat bantu yang benar-benar baik agar proses belajar menjadi efektif, menarik dan interaktif serta menyenangkan merupakan suatu permasalahan yang perlu dicarikan solusinya. Alat bantu atau media belajar mandiri pada era kemajuan teknologi saat ini sangat dibutuhkan dalam proses belajar. Hal ini dibutuhkan untuk menciptakan kualitas manusia yang tidak hanya bergantung melalui transfer ilmu secara verbal, baik yang dilakukan oleh sekolah maupun perguruan tinggi ataupun lembaga pendidikan nonformal saat ini, (Ginanjar, 2010).

Email : nokad.star@gmail.com 


\subsection{Rumusan Masalah}

Dari uraian latar belakang diatas dapat dipaparkan permasalahan penelitian yaitu kurang efektifnya proses pembelajaran khususnya pada mata pelajaran Ilmu Pengetahuan Alam yang diterapkan oleh pengajar SMPN 15 Loa Janan dengan penjelasan materi melalui buku atau diktat yang menyebabkan siswa merasa jemu dan membosankan, sehingga diperlukan media pembelajaran dengan teknologi animasi dua dimensi (2D) melalui perangkat komputer, oleh karena itu diperlukan pembuatan perangkat lunak media pembelajaran IPA sesuai dengan standar kompetensi pokok bahasan sistem pencernaan makanan.

\subsection{Batasan Penelitian}

Batasan masalah dalam penelitian ini adalah :

a. Media pembelajaran ini hanya membahas sistem pencernaan makanan sesuai dengan standar kompetensi.

b. Media pembelajaran ini tidak dibuat dalam bentuk e-book, moodle, ataupun web based learning.

c. Penelitian tidak difokuskan pada pembuatan produk media pembelajaran non exact.

\subsection{Tujuan Penelitian}

Dengan dilakukannya penelitian diharapkan dapat memberikan manfaat bagi semua pihak, antara lain :

1. Mampu menghasilkan visualisasi peta Ruang Terbuka Hijau di Kecamatan Samarinda Ulu.

2. Membantu memberikan rekomendasi untuk kebijakan di dalam penentuan lokasi Ruang Terbuka Hijau.

3. Membantu menentukan lokasi Ruang Terbuka Hijau sesuai dengan kriteria yang diinginkan.

4. Bermanfaat sebagai rujukan pemerintah kota untuk penentuan lokasi baru sebuah daerah Ruang Terbuka Hijau sehingga dapat diterima pemanfaatannya oleh seluruh stakeholders wilayah kota Samarinda umumnya dan kecamatan Samarinda Ulu khususnya.

\subsection{Manfaat Penelitian} adalah :

Manfaat yang didapat dari penelitian ini

a. Menerapkan teknologi komputer kepada siswa dan guru di SMP Negeri 15 Loa Janan Samarinda.

b. Memudahkan guru dalam menyampaikan materi pelajaran IPA melalui bantuan media pembelajaran.

\section{TINJAUAN PUSTAKA}

\subsection{Pengertian Media Pembelajaran}

Kata media berasal dari bahasa latin dan merupakan bentuk jamak dari kata medium yang secara harfiah berarti perantara atau pengantar pesan dari pengirim ke penerima pesan. Banyak batasan yang diberikan orang tentang media. Asosiasi Teknologi dan Komunikasi Pendidikan (Association of Education and Communication Technology/AECT) di Amerika, membatasi media sebagai segala bentuk dan saluran yang digunakan orang untuk menyalurkan pesan atau informasi. (Gagne, 1970) menyatakan bahwa media adalah berbagai jenis komponen dalam lingkungan siswa yang dapat merangsangnya untuk belajar. Sementara itu (Briggs, 1970) berpendapat bahwa media adalah segala alat fisik yang dapat merangsang siswa untuk belajar.

\subsection{Pengertian Antarmuka Pemakai}

Fokus interaksi manusia dan komputer adalah perancangan dan evaluasi antarmuka pemakai (user interface). Antarmuka pemakai adalah bagian sistem komputer yang memungkinkan manusia berinteraksi dengan komputer.

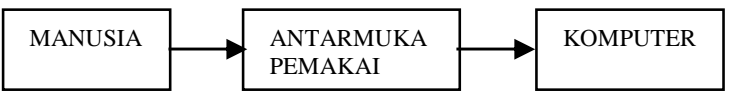

Gambar 1. Antarmuka Pemakai

Ada 4 kriteria yang harus dipenuhi sebagai antarmuka pemakai yang mudah (user-friendly), yakni :

1. Waktu belajar yang lama.

2. Kecepatan penyajian informasi yang tepat dan jelas.

3. Daya ingat pengguna setelah jangka waktu tertentu.

4. Kepuasan subjektif.

\subsection{Data Flow Diagram}

DFD adalah diagram alir data yang merupakan rincian dari diagram konteks, dimana DFD menunjukkan hubungan antara data pada sistem dan proses pada sistem.

Empat simbol dasar yang digunakan untuk memetakan gerakan diagram alir data antara lain :

1. Entitas

Entitas disebut sebagai sumber atau tujuan data dan dianggap eksternal terhadap sistem yang sedang di gambarkan. Setiap entitas diberi label nama yang sesuai.

2. Aliran Data

Aliran data di simbolkan dengan tanda panah yang menunjukan perpindahan data dari satu titik ke titik yang lain dengan kepala tanda panah mengarah ke tujuan data.

3. Proses

Proses merupakan apa yang di kerjakan oleh sistem. Proses dapat mengolah data atau aliran data masuk menjadi aliran data keluar. Proses berfungsi mentransformasikan satu atau 
beberapa data masukan menjadi keluaran sesuai dengan spesifikasi yang di inginkan.

4. Penyimpanan data

Penyimpanan data menunjukkan tempat di simpannya suatu data ke dalam sebuah file atau database basis data terkomputerisasi. Simbol- simbol yang digunakan dalam DFD dapat di lihat pada tabel 1 .

Tabel 1. Simbol (DFD)

\begin{tabular}{|c|c|c|}
\hline Simbol & Arti & Contoh \\
\hline & Entitas & SISWA \\
\hline & Aliran Data & $\begin{array}{l}\text { informasi siswa } \\
\text { baru }\end{array}$ \\
\hline & Proses & $\begin{array}{c}\text { Menyimpa } \\
\text { siswa }\end{array}$ \\
\hline & $\begin{array}{c}\text { Penyimpanan } \\
\text { Data }\end{array}$ & \\
\hline
\end{tabular}

\subsection{Software Yang Digunakan}

Untuk pembuatan media pembelajaran ini peneleti menggunakan beberapa software. Setiap data yang ada dipublish dengan cara digabungkan dari beberapa data.

1. Adobe Flash CS6 Professional

Adobe Flash CS6 Professional adalah sebuah program animasi yang telah banyak digunakan oleh para animator untuk menghasilkan animasi yang profesional. Di antara programprogram animasi, program Adobe Flash CS6 Professional merupakan program yang paling fleksibel dalam pembuatan animasi, seperti animasi interaktif, game, company profile, presentasi, Movie, E-card dan animasi yang digunakan dalam situs web

2. Adobe Photoshop CS

Adobe Photoshop CS adalah perangkat lunak standar editing gambar profesional yang membantu pengguna bekerja lebih efisien, mengeksploitasi kreatifitas dan menghasilkan gambar dengan kualitas tertinggi untuk web atau yang lainnya.

\subsection{Tinjauan Tentang Bab Sistem Pencernaan Makanan}

1. Makanan

Setiap makhluk hidup membutuhkan makanan. Tanpa makanan, makhluk hidup akan sulit dalam mengerjakan aktivitas sehariharinya.. Setiap makanan mempunyai kandungan gizi yang berbeda. Protein, karbohidrat,

dan lemak adalah salah satu contoh gizi yang akan didapatkan dari makanan.

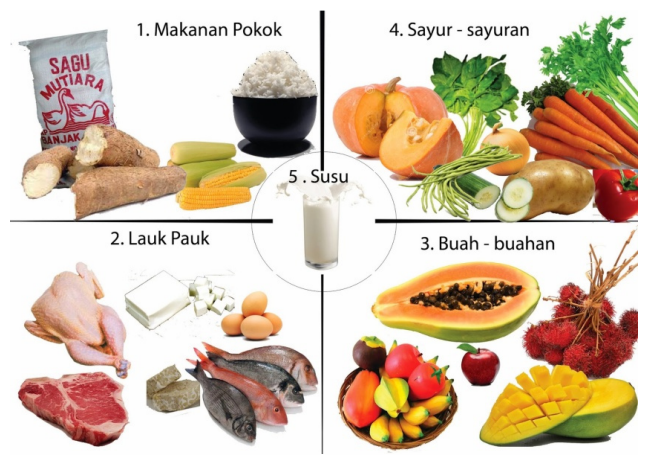

Gambar 2. Makanan

2. Saluran Pencernaan Makanan

Secara spesifik, Organ yang termasuk dalam sistem pencernaan terbagi menjadi dua kelompok:

a. Saluran pencernaan

Saluran pencernaan merupakan saluran yang berlanjut berupa tabung yang dikelilingi otot. Saluran pencernaan mencerna makanan, memecahnya menjadi bagian yang lebih kecil dan menyerap bagian tersebut menuju pembuluh darah. Organ-organ yang termasuk di dalam nya adalah: mulut, faring, kerongkongan, lambung, usus halus serta usus besar. Dari usus besar makanan akan dibuang keluar tubuh melalui anus.

b. Organ pencernaan tambahan

Organ pencernaan tambahan ini berfungsi untuk membantu saluran pencernaan dalam melakukan kerjanya. Gigi dan lidah terdapat dalam rongga mulut, kantung empedu serta kelenjar pencernaan akan dihubungkan kepada saluran pencernaan melalui sebuah saluran. Kelenjar pencernaan tambahan akan memproduksi sekret yang berkontribusi dalam pemecahan bahan makanan. Gigi, lidah, kantung empedu, beberapa kelenjar pencernaan seperti kelenjar ludah, hatidan pankreas.

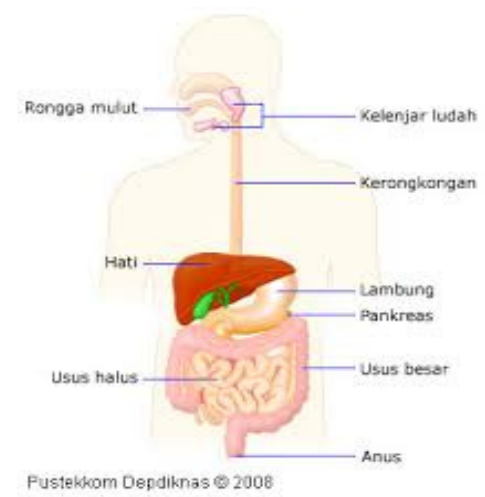

Gambar 3. Saluran pencernaan makanan 


\section{HASIL PENELITIAN DAN PEMBAHASAN}

\subsection{Hasil Penelitian}

Dari hasil penelitian yang dilakukan maka dapat disimpulkan standar kompetensi aplikasi media pembelajaran pokok bahasan sistem pencernaan makanan, meliputi :

a. Makanan dan saluran pencernaann

b. Istilah - istilah penting yang ada pada sistem pencernaan makanan.

Fungsi Multimedia dalam media pembelajaran diuraikan sebagai berikut :

1) Menampilkan Kategori Materi

2) Menampilkan Materi dan deskripsi Materi

3) Menampilkan Daftar isi dan Standar Kompetensi

4) Menampilkan Kuis dan Evaluasi Materi

\subsection{Implementasi System}

1. Opening

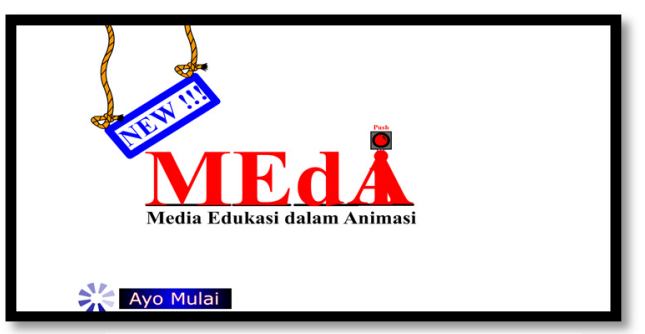

Gambar 4. Opening Program

Opening aplikasi ini adalah animasi pembuka sebelum masuk ke menu utama

2. Menu Home

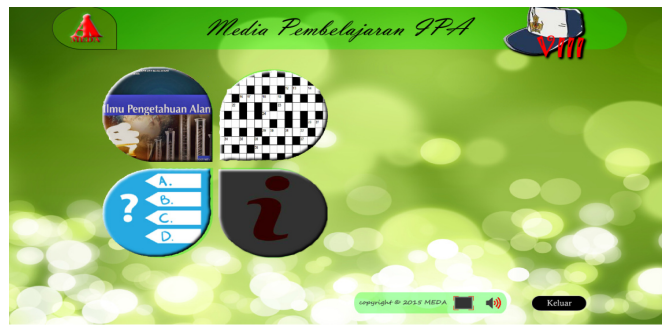

Gambar 5. Menu Home

Di dalam menu home ini menampilkan menu utama berupa materi, kuis, game dan tentang dari media pembelajaran IPA serta terdapat tombol full screen, suara, help dan keluar.

3. Menu Materi

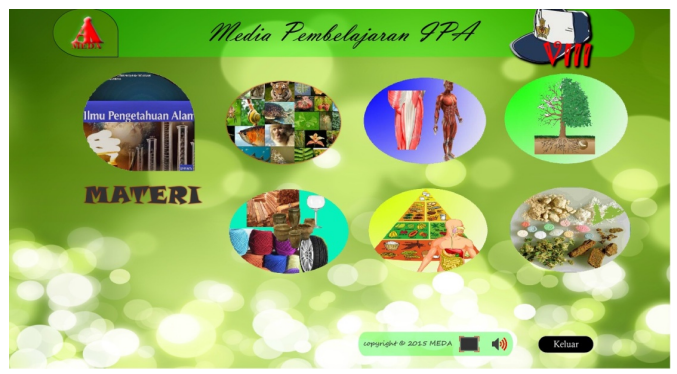

Gambar 6. Menu Materi
Halaman materi ditampilkan pada gambar 6 di atas. Di dalam halaman ini menampilkan materi, yang di dalamnya terdapat 5 materi yaitu gerak pada makhluk hidup dan benda, rangka, otot, dan pesawat sederhana, struktur dan fungsi jaringan pada tumbuhan serta pemanfaatannya dalam teknologi, sifat bahan dan pemanfaatannya dalam kehidupan seharihari, sistem pencernaan makanan, serta zat aditif dan adiktif

3. Daftar Isi

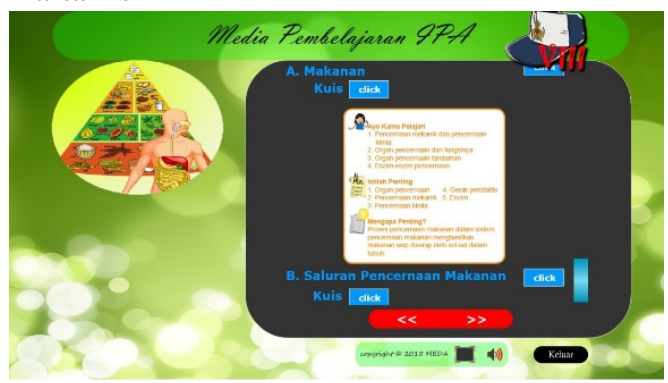

Gambar 7. Daftar Isi

Halaman daftar isi ditampilkan pada gambar 4.4 diatas. Di dalam menu materi 4 yang merupakan pokok bahasan Sistem Pencernaan Makanan, terdapat materi per sub bab yang bisa di scroll, yaitu Makanan, dan Saluran Pencernaan Makanan. Selain itu juga terdapat tombol click materi per sub bab dan kuis per sub bab dengan tombol tersebut memudahkan pengguna langsung ke menu materi per sub bab ataupun kuis per sub bab.

Pada halaman ini menampilkan materi per sub-bab Sistem Pencernaan Makanan

a. Makanan

Halaman materi makanan ditampilkan pada gambar 8 berikut ini.

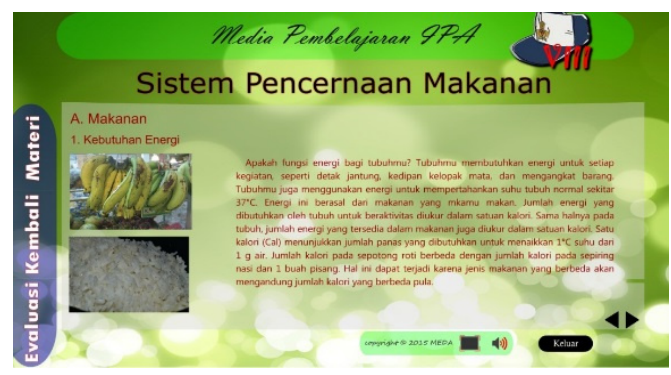

Gambar 8. Materi Sub-Bab

b. Saluran Pencernaan Makanan

Halaman materi saluran pencerrnaan makanan ditampilkan pada gambar 9 berikut ini. 


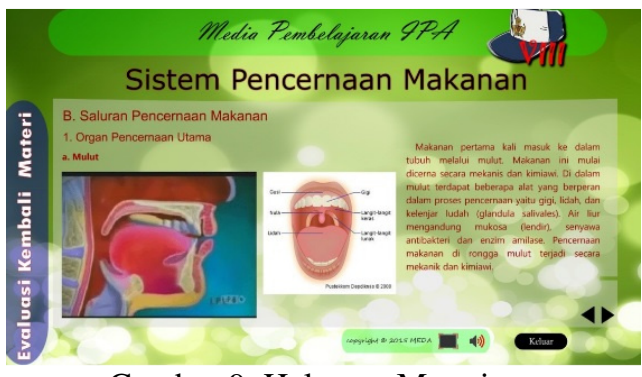

Gambar 9. Halaman Materi

c. Akhir Materi

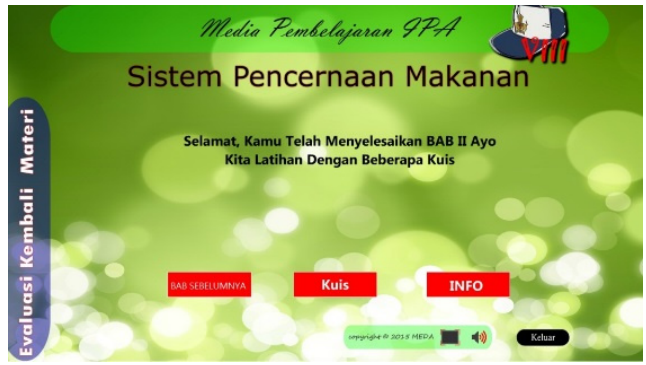

Gambar 10. Akhir Materi

Halaman akhir materi ditampilkan pada gambar 10 sebelumnya tampil setelah materi per sub bab selesai, maka akan diberitahukan bahwa materi per sub bab telah selesai, pengguna bisa memilih latihan kuis atau ke bab selanjutnya dengan mengklik tombol kuis dan tombol $\mathrm{Bab}$ Selanjutnya.

\section{Menu Game}

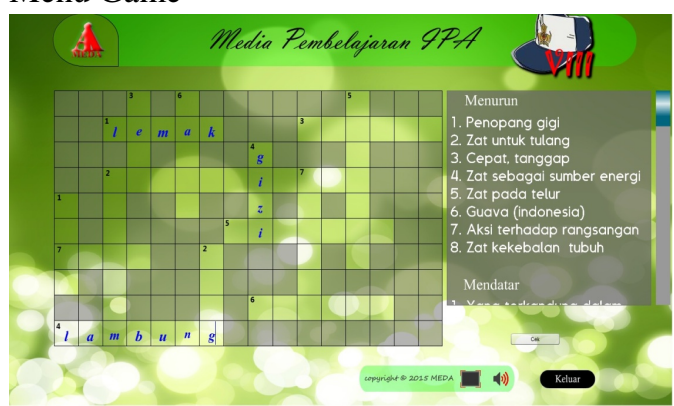

Gambar 11. Menu Game

Di dalam menu ini menampilkan game tekateki silang yang di ambil dari materi media pembelajaran ipa. Cara kerjanya adalah pengguna harus menginputkan karakter kedalam kotak yang kosong sesuai dengan clue yang tertera pada layar sebelah kanan. Jika pengguna sudah menyelesaikannya maka klik tombol cek, tombol ini berfungsi untuk mengecek jawaban pada kotak benar atau salah, jika benar maka akan diarahkan menuju frame selanjutnya.

5. Menu Evaluasi

Di dalam halaman ini menampilkan berupa kuis dari kuis 1 sampai dengan kuis 6 . pengguna bisa memilihkuis apa yang diinginkan.

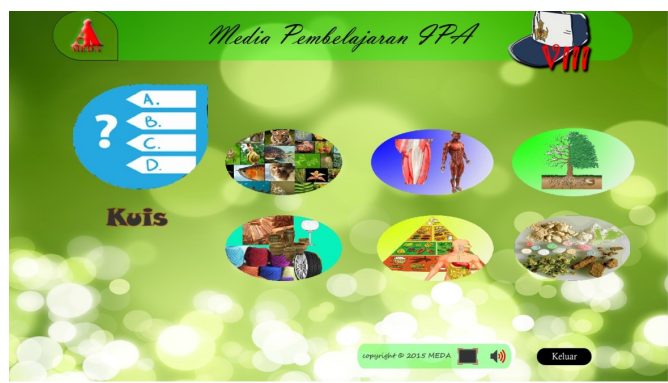

Gambar 12. Menu Evaluasi

Di halaman ini menampilkan latihan berupa evaluasi yang terdapat 50 soal sesuai dengan materi Sistem Pencernaan Makanan serta terdapat score jika pertanyaan berhasil dengan nilai maksimal sebesar 100 poin.

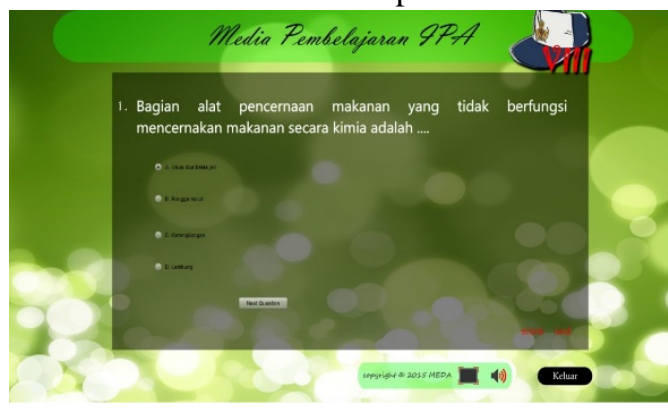

Gambar 13. Latihan Soal

Jika pengguna menjawab soal maka nilai yang diberikan adalah 4 untuk setiap soal yang benar, dan jika pengguna menjawab soal dengan salah maka nilai akan tetap. Setelah pengguna selesai menjawab soal evaluasi maka pengguna diarahkan ke halaman score. Seperti contoh gambar 14 dibawah merupakan hasil dari soal-soal evaluasi yang telah dijawab.

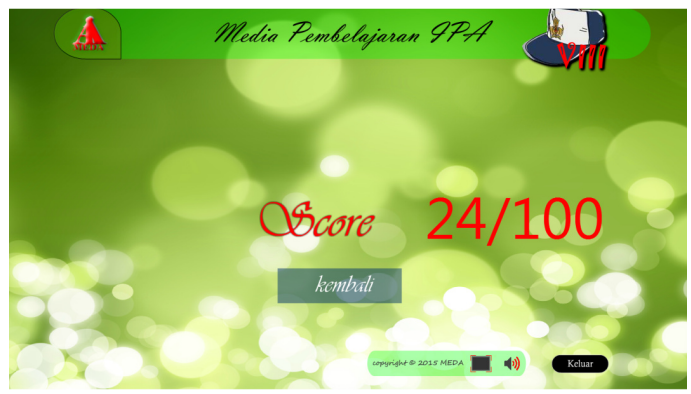

Gambar 14. Halaman Score

6. MenuAbout

Didalam menu tentang ini menampilkan fotofoto tentang kelompok team MEdA.

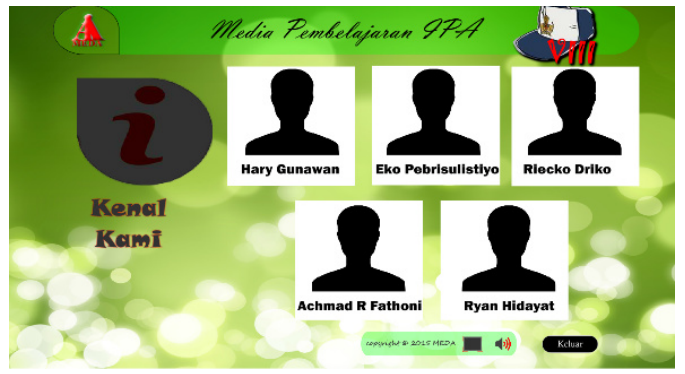

Gambar 15. Menu Kelompok Team 


\section{MenuKeluar}

Di dalam menu keluar ini menampilkan pilihan tombol Ya dan Tidak. Pengguna bisa memilih Ya jika ingin keluar dari program sedangkan Tidak kembali ke menu utama.

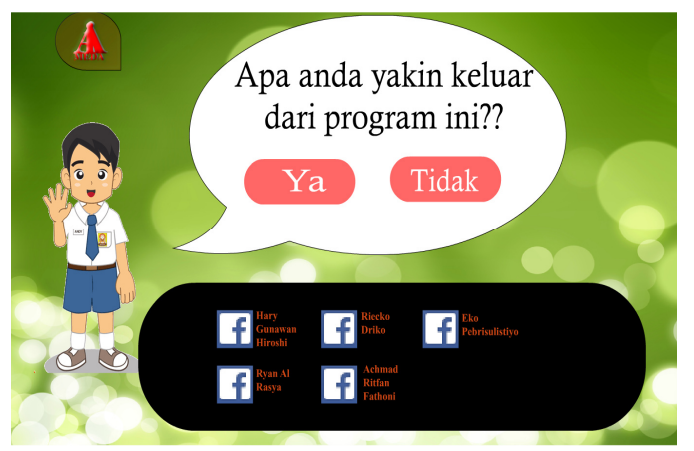

Gambar 16. Halaman Menu Keluar

\subsection{Pembahasan}

Pada pembahasan hasil media pembelajaran berupa pokok bahasan Sistem Pencernaan Makanan sesuai standar kompetensi ini telah selesai dibuat sesuai rencana dari cara menganalisis terlebih dahulu latar belakang masalah dan manfaatnya lalu mendesain bentuk visualisasi materi yang menarik. Dari hasil pengujian yang dilakukan, merujuk pada silabus mata pelajaran IPA dengan kompetensi dasar mengidentifikasi sistem pencernaan makanan yang ada di SMP Negeri 15 Loa Janan dengan indikator pencapaian kompetensi yaitu:

1. Menjelaskan jenis makanan serta penjabaran nya.

2. Menunjukkan dan menjelaskan letak saluran saluran pencernaan yang ada di dalam tubuh manusia.

Dengan demikian aplikasi yang dibuat ini sudah sesuai standar kompetensi, dilihat dengan terdapatnya materi sesuai dengan indikator pencapaian kompetensi.

\section{KESIMPULAN DAN SARAN \\ 4.1 Kesimpulan}

Berdasarkan hasil penelitian dan penerapan, kesimpulan dari hasil penelitian yang dilakukan adalah :

a. Media Pembalajaran IPA Sistem Pencernaan Makanan ini menggunakan pendekatan metode Sekuensial Linier / Waterfall, dimana dilakukan dengan tahap-tahap dan alur-alur dalam merancang sistem media pembelajaran IPA ini dengan cara menganalis terlebih dahulu masalah dan manfaatnya, mendesain, serta membuat coding, setelah itu memeriksa hasilnya.

b. Penerapan media pembelajaran IPA sistem pencernaan makanan dapat membantu guru dalam kegiatan belajar mengajar melalui teknologi komputer, serta meningkatkan minat dan kemauan siswa dalam belajar, dengan adanya media pembelajaran ini diharapkan juga dapat membangun budaya belajar melalui pengembangan pembelajaran e-learning.

\subsection{Saran}

Penulis sangat menyadari bahwa penelitian yang dilakukan ini masih memiliki banyak kekurangan dan kelemahan. Saran yang dapat diberikan adalah :

a. Media Pembelajaran IPA Sstem Pencernaan Makanan berbasis flash ini memiliki visualisasi yang hanya mencakup 2 dimensi, berupa gambar dan animasi sehingga perlu dilakukan pengembangan pada sisi visualisasi yang lebih menarik dan edukatif bahkan bisa dikembangkan lagi dengan tampilan 3 dimensi.Media pembelajaran IPA Sistem Pencernaan Makanan berbasis flash ini bisa juga dikembangkan ke ranah mobile aplikasi, seperti android system informasi yang dibuat masih memungkinkan untuk dikembangkan kearah yang lebih baik lagi dengan menggunakan metode-metode yang lain seperti spiral dan prototype.

\section{DAFTAR PUSTAKA}

[1] Anisyah. 2000. "Analisa dan Desain Sistem Informasi”. Yogyakarta: Andi Offset.

[2] Arief S. Sadiman, dkk. 2009. "Media pendidikan: Pengertian, Pengembangan, dan Pemanfaatannya”. Jakarta: Rajawali.

[3] Arsyad, Azhar. 2009. "Media pembelajaran". Jakarta: Raja Grafindo Persada.

[4] Bin Ladjamudin, Al Bahra, 2006. "Rekayasa Perangkat Lunak". Tangerang: Graha Ilmu.

[5] Dhanta, Rizky. 2009. "Kamus Istilah Komputer Grafis \& Internet”. Surabayat : Indah.

[6] Diningrat dan Mudjiono. 1994. "Belajar Dan Pembelajaran “. Jakarta: P2LPTK.

[7] Dr. Arief S. Sadiman, M. Sc., dkk. 2009. "Media Pendidikan" . Jakarta: Raja Grafindo Persada.

[8] Ginanjar, Anton. 2010. "Pengembangan Media Pembelajaran Modul Interaktif Mata Kuliah Pemindahan Tanah Mekanik". Skripsi. Surakarta: Fakultas Keguruan dan Ilmu Pendidikan, Universitas Sebelas Maret.

[9] Kenneth, E.k dan Julie, E.k. 2006. "Analis dan Perancangan Sistem.” Jakarta : Indeks. 